\title{
An atypical neurologic complication of Kikuchi-Fujimoto Disease
}

Mohamed Shabana, MD, and Worthy Warnack, MD

Neurol Neuroimmunol Neuroinflamm 2020;7:e707. doi:10.1212/NXI.0000000000000707
Correspondence

Dr. Shabana

Mohamed.Shabana@phhs.org

Kikuchi-Fujimoto disease (KFD) is a histiocytic necrotizing lymphadenitis that was first described in Japan in 1972. It is most commonly seen in women younger than the age of 30 years. The typical presentation includes cervical lymphadenopathy, fever, and cutaneous rash. Less often, KFD can present with axillary and mesenteric lymphadenopathy, splenomegaly, parotid gland enlargement, arthralgia, myalgia, and interstitial lung disease. Diagnosis of KFD is made when a lymph node biopsy shows necrotizing lymphadenitis with karyorrhexis and absence of granulocytes. The etiology of the disease is unknown, but an autoimmune or a postinfectious process has been proposed. Parvovirus 19, hepatitis B, HTLV-1, and toxoplasma are believed to be associated with KFD. ${ }^{1}$ The disease is selflimiting. In rare cases, neurologic complications including meningoencephalitis, cerebellar ataxia, encephalitis with CNS lesions, and most commonly aseptic meningitis have been described. ${ }^{1-5}$

We report here, a case of focal weakness and associated subcortical CNS lesions in a patient with Kikuchi-Fujimoto disease.

\section{Case presentation}

This is a 29-year-old Hispanic woman with a recent diagnosis of Kikuchi-Fujimoto disease who presented with weakness in her left upper extremity. She initially presented with a 2- to 3-month history of generalized arthralgia, fever, and cervical lymphadenopathy. She was found to have an elevated AST (619), ALT (438), and Alk Phos (131 with peak of 229 at day 9). Hepatitis Bc IgM was positive, whereas hepatitis Bs and Be antigens and antibodies were negative. Both infectious disease and hepatology consultants agreed that the hepatitis $\mathrm{Bc}$ IgM finding was false positive, given that liver function testing was inconsistent with acute hepatitis B. Hepatitis A, hepatitis C, HIV, T-Spot, sputum AFB culture, parvovirus, cytomegalovirus PCR, and cytomegalovirus IgM were negative. Antinuclear antibody, rheumatoid factor, and mitochondrial and smooth-muscle antibody were also negative. Cervical lymph node core biopsy and excision was performed, which demonstrated necrotizing lymphohistiocytic proliferation. Cervical lymph node excision ruled out evidence of infection or malignancy. A bone marrow biopsy showed slightly hypocellular bone marrow with trilineage hematopoiesis (no increase in blasts or atypical lymphoid infiltrates). Fungal culture of needle aspiration was negative. Given the patient's age, presence of multifocal lymphadenopathy, fever of unknown origin, and nonspecific autoimmune serology, she was diagnosed with KFD. She was treated with oral prednisone $40 \mathrm{mg}$ once a day for 5 days ( 2 doses inpatient and 3 outpatient) only because of persistent generalized arthralgia. A week later, she presented again with 7 days of progressive distal left upper extremity weakness with $0 / 5$ finger extension weakness. No evidence of cognitive, cerebellar, sensory, or gait impairment was found. 


\section{Neurologic evaluation}

At the time of her second presentation, she had recovered from previous systemic symptoms of arthralgia, fever, and pain. Her transaminitis was improved (AST-50, ALT-55, and Alk Phos129). MRI of the brain with and without contrast on admission showed a $3.5 \mathrm{~cm} \mathrm{AP} \times 3.0 \mathrm{~cm}$ transverse heterogeneous lesion in the right basal ganglia and a smaller enhancing lesion in the left caudate (figure 1) with evidence of hemosiderin deposition and partial diffusion restriction (figure e-1, links.lww.com/NXI/ A230). MRI of the cervical spine demonstrated persistent lymphadenopathy compared with previous $\mathrm{CT}$ of the neck with no cord evolvement. MRI angiography (MRA) of the head and neck was negative for evidence of an occlusion or vasculitis. There was no previous brain imaging for comparison. Lumbar puncture demonstrated $45 \mathrm{mg} / \mathrm{dL}$ glucose, $40 \mathrm{mg} / \mathrm{dL}$ protein, $4 / \mathrm{mcL}$ nucleated cells with $80 \%$ lymphocyte predominance, $1.06 \mathrm{IgG}$ index (normal <0.66), 0 oligoclonal bands, and acellular cytology. HSV, VZV, and EBV PCRs of the CSF were

Figure 1 Evolution of MRI of the brain with contrast over 4 months

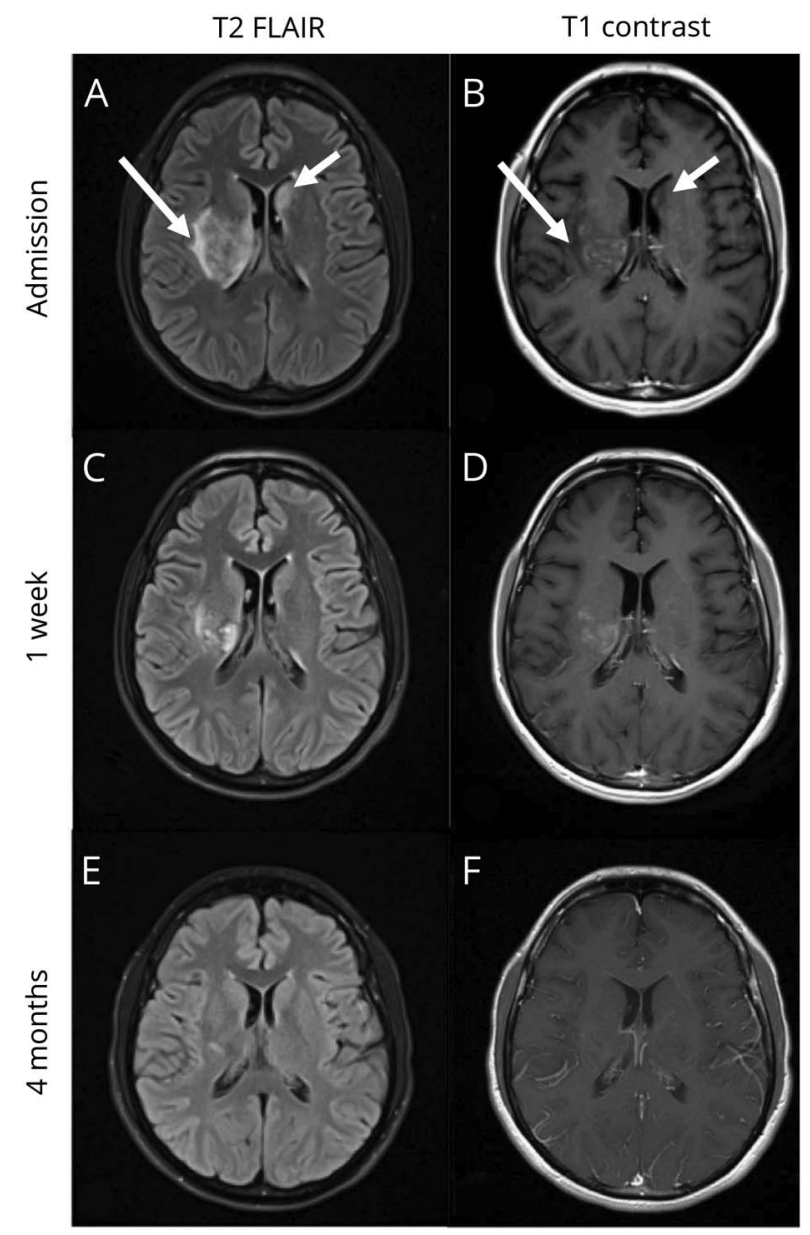

MRI of the brain on admission ( $A$ and $B$ ) demonstrated lesions in the right basal ganglia (long arrow) and left caudate (short arrow). Imaging after 1 week ( $C$ and $D$ ) shows a decrease in the size and enhancement of the lesions. Repeat imaging 4 months ( $E$ and $F$ ) after the onset demonstrates near resolution of the lesions. negative. The MR spectroscopy findings were normal. Her strength improved with physical and occupational therapy. No immune modulating therapy, steroids, or antibiotics were given during her second presentation. Procurement of a biopsy was considered; however, repeat MRI of the brain obtained 1 week after the one on admission showed a reduction in enhancement and T2 flare of the lesions (figure 1). Given the patient's clinical and radiographic improvement, a decision was made for conservative management with outpatient observation and occupational therapy. At 4 months of follow-up, there was near complete resolution radiographically and clinically (figure 1).

\section{Discussion}

The patient's presentation is considered to be an atypical complication of Kikuchi-Fujimoto disease. Although no brain biopsy was performed, this was a diagnosis of exclusion based on age, risk factors, resolution of the brain lesions, and previous diagnosis of KFD. A vascular etiology was unlikely because she had no risk factors for stroke, had atypical imaging of the brain lesions, rapid resolution of the lesions, and there were no vascular abnormalities on the MRI of the head and neck.

A demyelinating disorder was considered because of age, sex, and acute neurologic change with associated lesions. The presence of hemorrhage, lack of oligoclonal bands in the CSF, and rapid resolution without treatment is atypical of a demyelinating disorder but has been noted in rare cases. No metabolic or toxic sources were identified. There was a significant concern for malignancy beause of the heterogenicity of the lesion. The resolution of the lesion without intervention would be inconsistent with a malignancy. Given the recent diagnosis via cervical node biopsy, knowledge that KFD can lead to CNS involvement, improvement in the lesion without treatment, and rapid resolution, the lesion is a presumed complication of Kikuchi-Fujimoto disease. ${ }^{5}$

The unique aspect of this single case is the resolution with supportive management because she did not receive steroids or immunomodulating therapy since the onset of her weakness. This suggests that, in some cases, the CNS lesions of KFD may resolve with supportive care. However, patients with KFD and CNS lesions should still obtain a thorough workup because the disease process is not fully understood and the diagnosis in this case was one of exclusion.

\section{Study funding}

No targeted funding reported.

\section{Disclosure}

M. Shabana and W. Warnack report no disclosures. Go to Neurology.org/NN for full disclosures.

\section{Publication history}

Received by Neurology: Neuroimmunology \& Neuroinflammation June 3, 2019. Accepted in final form February 14, 2020. 


\begin{tabular}{lll}
\multicolumn{2}{l}{ Appendix } & Authors \\
\hline Name & Location & Contribution \\
\hline $\begin{array}{l}\text { Mohamed } \\
\text { Shabana, MD }\end{array}$ & $\begin{array}{l}\text { University of } \\
\text { Texas } \\
\text { Southwestern }\end{array}$ & $\begin{array}{l}\text { Collection of data, drafting the } \\
\text { manuscript, analysis of the data }\end{array}$ \\
\hline $\begin{array}{l}\text { Worthy } \\
\text { Warnack, } \\
\text { MD }\end{array}$ & $\begin{array}{l}\text { University of } \\
\text { Texas } \\
\text { Southwestern }\end{array}$ & $\begin{array}{l}\text { Drafting and revising the } \\
\text { manuscript, analysis of the data }\end{array}$ \\
\hline
\end{tabular}

\section{References}

1. Kucukardali Y, Solmazgul E, Kunter E, Oncul O, Yildirim S, Kaplan M. KikuchiFujimoto disease: analysis of 244 cases. Clin Rheumatol 2006;26:50-54.

2. Byun J-H, Park SE, Nam SO, et al. Three children of meningoencephalitis with Kikuchi necrotizing lymphadenitis. Brain Develop 2018;40:251-255.

3. Jasti D, Naveen Prasad S, Naveen T, Vengamma B. Kikuchi-Fujimoto disease presenting as brainstem encephalitis with secondary blepharospasm. J Neurosci Rural Pract 2016;7:157.

4. Moon J, Il Kim G, Koo YH, et al. Kinetic tremor and cerebellar ataxia as initial manifestations of Kikuchi-Fujimoto's disease. J Neurol Sci 2009;277:181-183.

5. Kido H, Kano O, Hamai A, et al. Kikuchi-Fujimoto disease (histiocytic necrotizing lymphadenitis) with atypical encephalitis and painful testitis: a case report. BMC Neurol 2017;17:22. 


\title{
Neurology \\ Neuroimmunology \& Neuroinflammation
}

\author{
An atypical neurologic complication of Kikuchi-Fujimoto Disease \\ Mohamed Shabana and Worthy Warnack \\ Neurol Neuroimmunol Neuroinflamm 2020;7; \\ DOI 10.1212/NXI.0000000000000707
}

This information is current as of March 16, 2020

\section{Updated Information \& Services}

References

Subspecialty Collections

Permissions \& Licensing

Reprints including high resolution figures, can be found at:

http://nn.neurology.org/content/7/3/e707.full.html

This article cites 5 articles, 0 of which you can access for free at: http://nn.neurology.org/content/7/3/e707.full.html\#\#ref-list-1

This article, along with others on similar topics, appears in the following collection(s):

All Immunology

http://nn.neurology.org//cgi/collection/all_immunology

Hematologic

http://nn.neurology.org//cgi/collection/hematologic

MRI

http://nn.neurology.org//cgi/collection/mri

Information about reproducing this article in parts (figures,tables) or in its entirety can be found online at:

http://nn.neurology.org/misc/about.xhtml\#permissions

Information about ordering reprints can be found online:

http://nn.neurology.org/misc/addir.xhtml\#reprintsus

Neurol Neuroimmunol Neuroinflamm is an official journal of the American Academy of Neurology.

Published since April 2014, it is an open-access, online-only, continuous publication journal. Copyright

Copyright $\odot 2020$ The Author(s). Published by Wolters Kluwer Health, Inc. on behalf of the American

Academy of Neurology.. All rights reserved. Online ISSN: 2332-7812.

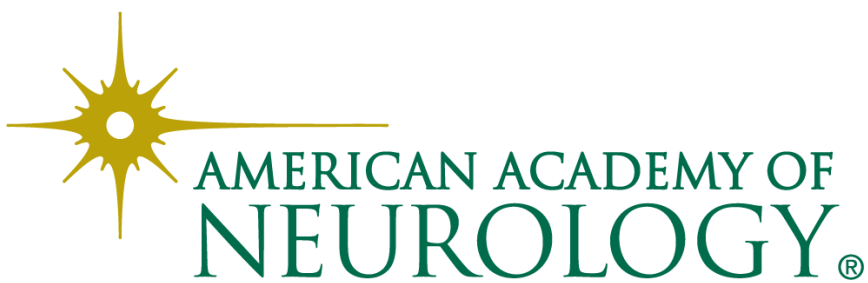

